Katarzyna Podyma

EJBISI Przedszkole Lingwistyczne z Oddziałami Integracyjnymi i Specjalnymi w Siemianowicach Śląskich

Instytut Twórczej Integracji w Sosnowcu

E-MAIL: katarzynap98@wp.pl orCID: oooo-ooo3-4968-0919

\title{
Wsparcie osób z niepełnosprawnością intelektualną na przykładzie mieszkalnictwa wspomaganego
}

\begin{abstract}
STRESZCZENIE
Koncepcja mieszkań wspomaganych została wielokrotnie opisana, jednak mimo to istnieje niewiele badań naukowych poświęconych zakresowi udzielanego wsparcia przez mieszkalnictwo wspomagane dla osób z niepełnosprawnością intelektualną. W związku z tym, przeprowadzając badania szukałam odpowiedzi na pytanie: jakie jest wsparcie osób $\mathrm{z}$ niepełnosprawnością intelektualną na przykładzie mieszkalnictwa wspomaganego? Badania zostały przeprowadzone $\mathrm{w}$ jednym $\mathrm{z}$ mieszkań wspomaganych dla osób z niepełnosprawnością intelektualną w Sosnowcu. Potrzebne materiały zebrałam metodą obserwacji bezpośredniej uczestniczącej i wywiadu bezpośredniego częściowo ustrukturyzowanego. Zaprezentowane badania ukazują zakres wsparcia udzielanego przez mieszkalnictwo wspomagane. Organizacja dnia, przygotowywanie posiłków, rozwiązywanie konfliktów to niezbędne umiejętności, które należy rozwijać już od najmłodszych lat życia.

SŁOWA KLUCzowE: osoby z niepełnosprawnością intelektualną, wsparcie, mieszkalnictwo wspomagane
\end{abstract}

\section{Wprowadzenie}

Osoby z niepełnosprawnością intelektualną spotykają się $\mathrm{w}$ codziennym życiu z różnymi trudnościami i problemami (Kutek-Sładek, 2015). By móc prowadzić jak najbardziej samodzielną egzystencję, powinni podejmować wszelkie działania, aby to osiągnąć. Uczęszczając do szkoły mogą liczyć na wsparcie wychowawców i nauczycieli. Po osiągnięciu pełnoletności tego rodzaju wsparcia mogą szukać w wielu instytucjach, czy korzystać z usług, które zmierzają do pomocy w nabywaniu umiejętności w zakresie samoobsługi i samodzielności. Jedną z takich usług jest mieszkalnictwo wspomagane (Marciniak-Madejska, 2014). To właśnie tutaj osoby z niepełnosprawnością intelektualną mają możliwość uczenia się normalnego życia na miarę osób pełnosprawnych. Temat podjęto $\mathrm{z}$ uwagi na chęć poznania zakresu wsparcia udzielanego przez mieszkalnictwo wspomagane. 
Aby wgłębić się w tę tematykę przeprowadzono badania, mające na celu poznanie i opisanie mieszkalnictwa wspomaganego jako wsparcia osób z niepełnosprawnością intelektualną. Sytuacja mieszkaniowa tych osób jest mniej sprzyjająca, niż w przypadku osób pełnosprawnych. Najczęściej mieszkają one z rodzicami lub są pod opieką placówki dla osób z niepełnosprawnością intelektualną (Marciniak-Madejska, 2013). Właściwą formą wsparcia prowadzącą do zmiany tej sytuacji jest mieszkalnictwo wspomagane. Rozważając na temat jego znaczenia, warto odwołać się do idei normalizacji, której istotą jest jak najbardziej „normalne” funkcjonowanie osób z niepełnosprawnością, biorąc pod uwagę ich wszelkie zaburzenia czy ograniczenia rozwojowe (Chrzanowska, 2019).

\section{Ujęcia definicyjne wsparcia i wsparcia społecznego}

Kluczowym aspektem jest wyjaśnienie pojęcia wsparcia. W ujęciu Zofii Kawczyńskiej-Butrym wsparcie oznacza „szczególny sposób i rodzaj pomocy udzielanej poszczególnym osobom i grupom głównie w celu mobilizowania ich sił, potencjału i zasobów, które zachowali, aby mogli sami sobie radzić ze swoimi problemami” (Kawczyńska-Butrym, 1998, s. 87-90). Wyróżnia ona następujące rodzaje wsparcia (Kawczyńska-Butrym, 1998):

- wsparcie informacyjne - przekazywanie wiedzy i informacji osobie o ograniczonej sprawności lub jego rodzinie, które dotyczą faktu zaistniałej niepełnosprawności, procesie rehabilitacji czy możliwościach leczenia, uprawnień, które będą w przyszłości przysługiwać, instytucjach, w których można znaleźć różne formy pomocy oraz o osobach znajdujących się w podobnej sytuacji;

- wsparcie emocjonalne - jest ono potrzebne w wyniku silnych przeżyć emocjonalnych, załamania po stracie sprawności, bądź urodzeniu niepełnosprawnego dziecka;

- wsparcie materialne - dostarczenie środków finansowych, darów, które ułatwią codzienne życie niepełnosprawnych osób;

- wsparcie przez świadczenie usług - pomoc w wykonywaniu określonych czynności dnia codziennego oraz te, które wymagają dużego wysiłku, na przykład mycie okien, załatwienie spraw w urzędzie;

- wsparcie w rozwoju - ukierunkowane jest na rozwój osoby niepełnosprawnej, np. pomoc przy nauce.

Helena Sęk uważa, że wsparcie społeczne jest rodzajem „interakcji charakteryzującej się dążeniem do rozwiązania problemu, przezwyciężenia trudności, 
reorganizacji zakłóconej relacji z otoczeniem i podtrzymania emocjonalnego. O wsparciu decyduje jakość interakcji, która umożliwia łagodniejszy odbiór trudności dzięki towarzyszeniu, tworzeniu poczucia przynależności i bezpieczeństwa oraz nadziei na rozwiązanie problemu" (Bakiera i Stelter, 2010, za: Sęk, 2001, s. 145). Wyróżnia ona pięć rodzajów wsparcia (Bakiera i Stelter, 2010):

- wsparcie emocjonalne - mając pozytywny stosunek wobec wspieranej osoby, daje się poczucie troski i empatii wobec niepełnosprawnej osoby i jej obecnej sytuacji;

- wsparcie informacyjne (poznawcze) - przekazywanie informacji, dzielenie się swoimi doświadczeniami, wiedzą instytucjonalną odnośnie do przepisów dotyczących wsparcia i działania różnych instytucji pomocowych. Dzięki tym działaniom osoba niepełnosprawna będzie miała poczucie, iż rozumiemy jej sytuację;

- wsparcie instrumentalne - polega na modelowaniu działań zaradczych lub ich okazywaniu oraz stymulacji rozwoju osób niepełnosprawnych;

- wsparcie rzeczowe (materialne) - dotyczy zorganizowania środków finansowych;

- wsparcie duchowe - przytoczenie sensu życia w przypadku sytuacji krytycznej.

Aleksandra Maciarz ma inny punkt widzenia na wsparcie społeczne. Określa je jako „różnorodną pomoc, dostępną w jej środowisku świadczoną przez różne instytucje, stowarzyszenia społeczne oraz osoby i inne rodziny, z którymi pozostaje w kontaktach więzi” (Maciarz, 1992, s. 254-257).

Podobnie pojęcie wsparcia społecznego rozumie Mieczysław Radochoński. W swoich rozważaniach określa je jako „różnorodną pomoc dostępną danej rodzinie poprzez więzy społeczne z innymi jednostkami, grupami, instytucjami" (Kutek-Sładek, 2015 za: Radochoński, 1991, s. 10). Wspomaganie społeczne dotyczy czterech podstawowych systemów (Kutek-Sładek, 2015 za: Radochoński, 1991):

- systemu wsparcia ekonomicznego - pomoc materialna;

- systemu usług - robienie zakupów, wsparcie podczas opieki nad dzieckiem;

- systemu wsparcia społecznego odwiedziny, spacery, celebrowanie różnych uroczystości;

- systemu wsparcia emocjonalnego - przeżycia uczuciowe podczas relacji międzyludzkich. 
Z powodu ograniczeń i dysfunkcji organizmu w różnych obszarach osoby $\mathrm{z}$ niepełnosprawnością mają prawo korzystać z systemu wsparcia (Kutek-Sładek, 2015). Singer i Lord wyodrębnili trzy źródła wsparcia (Kacperczyk, 2006 za: Singer i Lord, 1984, s. 23):

- osobiste (personal) - przyjaciele, znajomi, krewni;

- formalne (formal) - różnego typu organizacje charytatywne, instytucje powołane do pomagania, pomoc społeczna, kluby sportowe, wspólnoty kościelne;

- profesjonalne (professional) - poradnie profesjonalnie, zajmujące się pomaganiem i psychoterapią, specjalne grupy wsparcia.

Podsumowując powyższą część rozważań, trudno nie zauważyć, że system wsparcia jest niezbędnym elementem życia w przypadku osób z niepełnosprawnością. Wymagają one wsparcia m.in.: finansowego, emocjonalnego, społecznego czy przy likwidacji barier architektonicznych. Dzięki wsparciu mogą prowadzić życie na wyższym poziomie oraz w dalszym ciągu mogą pracować nad swoimi słabościami i dysfunkcjami rozwojowymi.

\section{Mieszkalnictwo wspomagane}

Osoby z niepełnosprawnością uczą się samodzielności i zdobywają kompetencje społeczne w różnych ośrodkach rehabilitacyjnych, czy w szkołach specjalnych, by móc w przyszłości prowadzić samodzielną egzystencję. W placówkach dla osób dorosłych z niepełnosprawnością są pracownie gospodarstwa domowego, gdzie osoby z niepełnosprawnością intelektualną uczą się gotować, prać, sprzątać, robić zakupy i gospodarować pieniędzmi. Cel rehabilitacyjny zostanie osiągnięty dopiero gdy, osoby z niepełnosprawnością intelektualną będą miały możliwość wykorzystać zdobyte umiejętności w warunkach pozainstytucjonalnych. Idealnym takim miejscem jest mieszkanie wspomagane (Marciniak-Madejska, 2014). Jaki pisze Natalia Marciniak-Madejska:

Mieszkalnictwo wspomagane będące formą rehabilitacji społecznej oznacza, procesualne przygotowanie osoby z niepełnosprawnością fizyczną, intelektualną i/lub sensoryczną (niezależnie od rodzaju i stopnia niepełnosprawności) do samodzielnej egzystencji, w tym do zamieszkania poza rodziną i wieloosobową placówką opieki całodobowej przy odpowiednim profesjonalnym wsparciu asystentów (Marciniak-Madejska, 2014, s. 103). 
Mieszkania wspomagane są przeznaczone dla każdej osoby z niepełnosprawnością intelektualną niezależnie od stopnia i rodzaju niepełnosprawności, która ukończyła 18 lat i jest gotowa na opuszczenie rodzinnego domu i samodzielne zamieszkanie (Marciniak-Madejska, 2014). Priorytetową grupą odbiorców mieszkań wspomaganych są (www.rpo.malopolska.pl/download/ Model_mieszka_wspomaganych_dla_niepenosprawnych_intelektualnie_31_ 08_2015.pdf, dostęp: 15.01.2020):

- uczestnicy środowiskowych domów samopomocy;

- uczestnicy warsztatów terapii zajęciowej;

- osoby objęte pomocą w formie specjalistycznych usług opiekuńczych;

- uczestnicy klubów i centrów integracji społecznej;

- mieszkańcy domów pomocy społecznej;

- osoby zatrudnione w zakładach aktywności zawodowej;

- osoby upośledzone umysłowo w stopniu lekkim i umiarkowanym.

Aby móc zamieszkać w mieszkaniu wspomaganym, należy przejść trening mieszkaniowy, który ma na celu przygotowanie osoby z niepełnosprawnością intelektualną do innego sposobu funkcjonowania. Rozpoczyna się on od weryfikacji umiejętności związanych z prowadzeniem gospodarstwa domowego oraz prowadzeniem samodzielnej egzystencji. Bardzo ważnym jego aspektem jest nauka planowania zadań życiowych w perspektywie długoterminowej, które należy wykonywać regularnie w dłuższych odstępach czasowych, czyli opłacanie rachunków raz w miesiącu, chodzenie do fryzjera, czy mycie okien oraz zadań życiowych w perspektywie krótkoterminowej, tj. utrzymywanie porządku, robienie zakupów, codzienna pielęgnacja oraz gotowanie (Marciniak-Madejska, 2014). Po zakończonym treningu taka osoba może zamieszkać już w mieszkaniu wspomaganym (Marciniak-Madejska, 2014).

Długość pobytu w mieszkaniu wspomaganym jest ustalana indywidualnie dla każdej osoby i jest ona zależna od celu pobytu. Pierwszym etapem jest okres próbny, który trwa nie dłużej niż 3 miesiące. Następnie dokonywana jest ocena sytuacji osoby, która zamieszkuje ten lokal. Po uzyskaniu pozytywnej oceny, czas pobytu w mieszkaniu wspomaganym jest wydłużany. Taką ocenę każdej osoby dokonuje się nie rzadziej, niż co 3 miesiące i w razie potrzeby zmienia się zakres i rodzaj świadczonego wsparcia. Długość pobytu w mieszkaniu może zostać ustalona na czas nieokreślony. Jest to możliwe w sytuacjach, kiedy z realizacji planu usamodzielnienia wynika, że osoba ta nie ma możliwości prowadzenia samodzielnego życia (zamieszkania) ze względu na 
deficyty intelektualne, sytuację materialną, wiek czy różne schorzenia. Jeśli osoba ta pozytywnie funkcjonuje dzięki otrzymywanym wsparciu, to również pobyt w mieszkaniu może zostać ustalony na czas nieokreślony (www.rpo. malopolska.pl/download/Model_mieszka_wspomaganych_dla_niepenosprawnych_intelektualnie_31_08_2015.pdf, dostęp: 15.01.2020).

Mieszkania wspomagane występują w różnych formach. Można podzielić je ze względu na liczbę osób zamieszkujących mieszkanie oraz ze względu na zakres wsparcia (Marciniak-Madejska, 2014):

Podział ze względu na liczbę osób zamieszkujących mieszkanie:

- indywidualne - osoba z niepełnosprawnością mieszka sama;

- partnerskie - w mieszkaniu mieszkają dwie osoby o tej samej, bądź różnej płci; ze względu na łączące ich relacje mogą mieć jeden wspólny pokój lub oddzielne pokoje;

- grupowe - w mieszkaniu mieszka od trzech do piętnastu osób z niepełnosprawnością intelektualną; osoby te mają indywidualne pokoje, bądź podwójne.

Podział ze względu na zakres wsparcia:

- czasowe - opieka asystencka trwa od kilkunastu godzin dziennie do kilku godzin miesięcznie;

- całodobowe - opieka asystencka jest całodobowa.

Jednym z głównych celów mieszkań wspomaganych jest integracja osób z niepełnosprawnością intelektualną ze środowiskiem osób pełnosprawnych, dlatego lokalizacja mieszkania powinna być w środowisku lokalnym (www.rpo. malopolska.pl/download/Model_mieszka_wspomaganych_dla_niepenosprawnych_intelektualnie_31_08_2015.pdf, dostęp: 15.01.2020). Dzięki takiemu umiejscowieniu mieszkania, osoby te mają możliwość uczestniczyć $\mathrm{w}$,życiu społeczno- kulturalnym społeczności lokalnej poprzez dostęp do instytucji publicznych, budynków handlowych, sieci obiektów rekreacyjnych, oświaty" (Marciniak-Madejska, 2014, s. 113).

Pobyt w mieszkaniu wspomaganym powinien nauczyć lub podtrzymać poziom sprawności w zakresie samoobsługi i czynności niezbędnych w dniu codziennym, dlatego też należy w dalszym ciągu ćwiczyć umiejętności praktyczne (pranie, sprzątanie, korzystanie z różnych urządzeń), czynności higieniczne i pielęgnacyjne, czynności kulinarne, umiejętności finansowe (gospodarowanie pieniędzmi), umiejętności spędzania czasu wolnego, umiejętności 
społeczne rozwiązywania wszelkich konfliktów i nauka zachowania się w wielorakich sytuacjach), załatwianie spraw w urzędach (www.rpo.malopolska.pl/download/Model_mieszka_wspomaganych_dla_niepenosprawnych_intelektualnie_31_08_2015.pdf, dostęp: 15.01.2020).

Podsumowując, mieszkania wspomagane są przeznaczone dla osób z niepełnosprawnością intelektualną. Pozwalają one uzyskać jak największą samodzielność, tak by osoby te mogły w przyszłości zamieszkać same i prowadzić samodzielną egzystencję.

\section{Metodologia badań własnych}

Celem przeprowadzonych badań było poznanie i opisanie mieszkalnictwa wspomaganego jako wsparcia osób z niepełnosprawnością intelektualną. Przeprowadzając badania starałam się znaleźć odpowiedź na następujący problem badawczy: jakie jest wsparcie osób z niepełnosprawnością intelektualną na przykładzie mieszkalnictwa wspomaganego? Badania zostały przeprowadzone w Sosnowcu, w jednym z mieszkań wspomaganych dla osób z niepełnosprawnością intelektualną. Mieszkania te są prowadzone przez fundację Instytut Twórczej Integracji (ITI). Badana grupa to podopieczni mieszkania wspomaganego. Obecnie w mieszkaniu mieszka 7 osób z niepełnosprawnością intelektualną w stopniu umiarkowanym lub znacznym, w tym jedna osoba z zespołem Downa. Mieszkańcy to osoby dorosłe, zarówno kobiety i mężczyźni, w wieku 19-53 lat. Na co dzień uczą się w szkole specjalnej, korzystają z usług Środowiskowego Domu Samopomocy lub pracują. Badana grupa to osoby w miarę samodzielne, jednakże potrzebujące wsparcia w czynnościach i sytuacjach dnia codziennego. Ponadto, w badaniu wzięło udział 2 opiekunów mieszkania wspomaganego.

Badania zostały przeprowadzone przy użyciu metod z orientacji jakościowej. Celem badań jakościowych jest zrozumienie badanego zjawiska. Bierze w nich udział dosyć mała liczba respondentów, przez co badacz ma możliwość osobiście zebrać potrzebne informacje. Badania jakościowe są zorientowane na proces, dlatego badacz stara się dotrzeć do istoty badanego zjawiska, sprawy. Stara się znaleźć odpowiedź na pytanie, dlaczego respondenci zachowują się w określony sposób oraz co jest przyczyną danego zachowania (Bendkowski, 2016).

Materiały potrzebne do analizy zostały zgromadzone dzięki zastosowaniu metody obserwacji bezpośredniej uczestniczącej. Dariusz Jemielniak opisując tę metodę, zwrócił uwagę, na fakt, iż badacz jednocześnie jest uczestnikiem i obserwatorem danej zbiorowości. Swoje spostrzeżenia na temat zaobserwowanych interakcji, czy zachowań zapisuje bądź dokumentuje w jakiś inny 
sposób. Przez zastosowanie tego rodzaju obserwacji łatwiej jest poznać i zaobserwować informacje, o których osoby badane często nie chcą opowiedzieć, bądź są dla nich tematem drażliwym (Jemielniak, 2012). Obserwacje mieszkańców odbywały się w ich naturalnym środowisku, jakim jest mieszkanie wspomagane. Protegowani nie byli poinformowani, że są obserwowani, co pozwoliło na poznanie ich naturalnych zachowań oraz postępowania podczas różnych sytuacji i czynności codziennych. Jak wiadomo, respondenci powinni dobrowolnie zgodzić się na udział w badaniu. Zadaniem badacza jest wyjaśnienie w zrozumiały sposób, czego będzie dotyczyć badanie, kto je będzie prowadził oraz w jaki sposób zostaną wykorzystane uzyskane wyniki (Nieporowski, 2015, za: Kodeks etyki socjologa, 2012). Tak więc, jak się to odnosi do wykorzystanej metody obserwacji bezpośredniej uczestniczącej, gdzie respondenci nie zostali poinformowani, że są obiektem badań? W Kodeksie etyki socjologa zapisano, że:

(...) w niektórych przypadkach, zastosowanie tej formy badań może być uzasadnione. Na przykład wówczas, gdy można przypuszczać, iż uczestnicy, wiedząc, że są badani, zmienią swoje zachowanie. Badacze mogą również napotykać trudności w dostępie do określonych sfer życia społecznego, które, ze względu na silne lub utajnione interesy, pozostają dla socjologów zamknięte. Metody badań niejawnych pozostają w sprzeczności z zasadami świadomej zgody i mogą naruszać prywatność badanych. Do obserwacji uczestniczącej i nieuczestniczącej w sferze niepublicznej bez wiedzy badanych, oraz do podejmowania badań eksperymentalnych z ukryciem przed badanymi ich prawdziwego celu naukowego, należy uciekać się wyłącznie wtedy, gdy inne metody nie wystarczają do pozyskania podstawowych danych (Nieporowski, 2015, za: Kodeks etyki socjologa, 2012, s. 71).

Należy chronić anonimowość uczestników oraz starać się o uzyskanie ich zgody po przeprowadzeniu badania (Nieporowski, 2015, za: Kodeks etyki socjologa, 2012).

W celu wzbogacenia materiału badawczego przeprowadzono wywiady niestandaryzowane, częściowo ustrukturyzowane z mieszkańcami oraz opiekunami mieszkania. Podczas przeprowadzania wywiadów, badacz miał możliwość decydowania o kolejności zadawania pytań, biorąc pod uwagę kontekst rozmowy. Wypowiedzi osób z niepełnosprawnością intelektualną, często są ubogie $\mathrm{w}$ istotne informacje, dlatego korzystając $\mathrm{z}$ tego rodzaju wywiadu badacz mógł zadawać pytania otwarte i zamknięte, dopytując o interesujące go kwestie (Jemielniak, 2012). Wywiady z respondentami zostały przeprowadzone w formie indywidualnej, w pokojach podopiecznych, co przyczyniło się do swobody i otwartości ich wypowiedzi. Aspekt wiarygodności uzyskanych informacji jest istotny w toku przeprowadzania wywiadu. Na jego wpływ ma 
respondent, który może celowo podać fałszywe informacje przed obawą, że jego wypowiedź może spotkać się z negatywną oceną ankietera lub obawą przed narażeniem się panującym stereotypom i konwenansom $\mathrm{w}$ danej zbiorowości. Kolejnym czynnikiem zakłócającym wiarygodność uzyskanych informacji jest kwestionariusz wywiadu, gdzie zastosowany język będzie niedostosowany do respondentów. Trzecim czynnikiem jest sam prowadzący badanie. Istnieją badania, gdzie do przeprowadzania wywiadów jest zaangażowanych więcej osób, wtedy też powinno się przeprowadzić instruktaż z ankieterami na temat rozumienia pytań oraz przywiązania jednakowej uwagi do wszystkich problemów (Pilch, 1998). W toku przeprowadzania wywiadów wypowiedzi respondentów nie spotkały się z ocenami badacza, ponadto język zadawanych pytań był dostosowany do poziomu funkcjonowania badanych osób.

Do przeprowadzenia wywiadów z mieszkańcami i opiekunami posłużono się dyspozycjami do wywiadó ${ }^{1}$, natomiast $\mathrm{w}$ przypadku obserwacji schedułami obserwacji². Dyspozycje do wywiadów z mieszkańcami obejmowały 14 pytań, które dotyczyły obowiązków, zadań, czasu wolnego w dni powszednie i wolne. Natomiast dyspozycje do wywiadów z opiekunami obejmowały 5 pytań i dotyczyły organizacji życia mieszkańców i wsparcia.

\section{Wyniki badań}

Głównym celem mieszkania wspomaganego jest nauka samodzielności i codziennego życia. Osoby z niepełnosprawnością intelektualną w stopniu umiarkowanym i znacznym stale potrzebują wsparcia w codziennym funkcjonowaniu ze strony opiekuna (Zasępa, 2017).

W większości, osoby te nie znają wartości pieniądza, dlatego wszelkie opłaty za rachunki należą do obowiązków opiekuna. Codzienne życie człowieka przebiega według określonego scenariusza (Sztompka i Bogunia-Borowska, 2008). Mieszkańcy przez swoje deficyty mają trudności w prowadzeniu dnia według struktury, dlatego ich życie w głównej mierze jest

1 Dyspozycje do wywiadu są przypisane głównie do wywiadu swobodnego, jednakże ze względu na poziom funkcjonowania rozmówców oraz ich ubogie w istotne informacje wypowiedzi posłużono się nimi, pomimo że zastosowano metodę wywiady niestandaryzowanego, częściowo ustrukturyzowanego. Dyspozycje do wywiadu są wykazem potrzeb informacyjnych badacza. Tworząc je przygotowuje się wzory pytań, dotyczące poszczególnych zagadnień. Badacz przeprowadzając wywiad nie musi z nich korzystać, jeśli nie dają one oczekiwanych efektów. Tok wywiadu, treść i użyty język wszystkich pytań powinien być dostosowany do możliwości badanych osób (Przybyłowska, 1978).

2 Scheduła obserwacji- „specjalny zestaw (lista) poszczególnych kategorii zachowań osób badanych, istotnych z punktu widzenia interesującego badacza problemu”(Łobocki, 2003, s. 6o). 
organizowane przez opiekunów mieszkania. To właśnie oni nakreślają zakres i kierunek działań.

\begin{abstract}
Wydaje mi się, że wspólnie staramy się organizować życie mieszkańców (opiekun i mieszkaniec). Niestety bez pomysłu opiekuna na to co można zrobić, jak ma wyglądać dzień/tydzień sami mieszkańcy najczęściej nie mają pomysłu. Mieszkańcy poza telefonem i Internetem raczej nie mają innych pomysłów np. na spędzanie czasu wolnego. $(\mathrm{O} 1)^{3}$

Właściwe to na to pytanie jest podwójna odpowiedź. Z jednej strony życie mieszkańców organizowane jest przez opiekunów. To oni muszą nadać kierunek działania. Mieszkanie jest dla osób zależnych, niepełnosprawnych intelektualnie. Nie mieszkają sami w sensie nie planują swojego dnia od początku do końca, nie płacą rachunków itp. To opiekun (grupa opiekunów ) nakreśla strukturę i funkcje tego mieszkania. Z drugiej strony w czynnościach domowych, takich jak sprzątanie, przygotowanie posiłków, to mieszkańcy dbają o swoją przestrzeń. To nie jest tak, że osoby z NI w znacznym i umiarkowanym stopniu organizują swoje życie. Osoby te potrzebują wsparcia w obszarze codziennego funkcjonowania i o tym nie należy zapominać. $\left(\mathrm{O}_{2}\right)$
\end{abstract}

Podopieczni mieszkania wspomaganego nie mają pomysłu na organizowanie swojego życia. Ich zasoby na możliwość spędzania czasu wolnego są ubogie. Dlatego aspekt ten należy do opiekunów mieszkania. To oni organizują mieszkańcom czas wolny, proponują różne aktywności oraz wychodzą z inicjatywą na wspólną grę w chińczyka, bilarda czy upieczenie ciasta.

Mieszkańcy poza telefonem i Internetem raczej nie mają innym pomysłów np. na spędzanie czasu wolnego. (O1)

Jednym z celów pobytu w mieszkaniu wspomaganym jest rozwijanie umiejętności społecznych, czyli między innymi rozwiązywanie konfliktów (http:// www.rpo.malopolska.pl/download/Model_mieszka_wspomaganych_dla_ niepenosprawnych_intelektualnie_31_08_2015.pdf, dostęp: 15:01.2020). Jak wynika z obserwacji i wywiadów, mieszkańcy cały czas wymagają ćwiczenia tej umiejętności, gdyż zdarza się, że niektóre kłótnie rozwiązują dzięki spokojnej rozmowie, jednak większość kończy się krzykiem, czy trzaskaniem drzwiami. Aby osiągnąć ten cel, opiekunowie postanowili zorganizować każdego dnia o godzinie 20.00 Społeczność, czyli spotkanie mieszkańców i opiekunów, podczas którego rozmawia się o minionym dniu oraz rozstrzyga wszelkie nieporozumienia.

3 Oznaczenie „Oı” lub „O2” pozwala odróżnić wypowiedzi poszczególnych opiekunów, uczestniczących w badaniu. 
(...) Ale potem się godzimy. Gadamy, rozmawiamy no i się godzimy. Czyli rozmowa jest nam potrzebna, tak. Rozmowa. (J, 1. 23)

Z krzykiem, bo G jest nerwus. J tak samo. Wszyscy są nerwusy. Ale ja nic nie poradzę. To co mam zrobić ? Idę do pokoju i trzaskam drzwiami i siedzę w pokoju i nie wychodzę nawet do kolacji. (D, 1. 53)

Społeczność to jest jak siedzi przy stole i się opiekunka pyta co my robiliśmy dzisiaj, to znaczy że, czy była zadowolona z naszej roboty, czy nie, jakie zachowanie w stosunku do kolegów, do koleżanek. No takie, czy żyjemy rodzinnie, spokojnie i się nie kłócimy, nie bijemy. (D, 1.53)

Rozmawiamy sobie, żeby się nie kłócić (...). (G, l.36)

Codzienne życie wielu osób, w tym osób z niepełnosprawnością intelektualną wiąże się z różnymi trudnościami i problemami (Kutek-Sładek, 2015). Ze względu na swój poziom funkcjonowania osoby te korzystają ze wsparcia w codziennym życiu. Wywiady i obserwacje ukazują, że obszary wsparcia z jakich korzystają mieszkańcy to m.in.: przygotowywanie posiłków, załatwianie spraw w urzędzie i u lekarza oraz zachowanie się w trudnych sytuacjach. To właśnie opiekunowie mieszkania są odpowiedzialni za udzielenie oparcia w tych obszarach.

(...) Wsparcia potrzebują w obszarze emocjonalnego (radzenie się w sytuacjach trudnych - dla nich trudnych, materialnych - w wydawaniu pieniędzy, - czy planowaniu dnia. $\left(\mathrm{O}_{2}\right)$

Mieszkańcy potrzebują nieustannego wsparcia. Obszary są różne w zależności od osoby i od tego z jakimi umiejętnościami przychodzi do domu. Najczęstsza pomoc to pomoc w czynnościach domowych, przygotowywaniu posiłków, zrobieniu zakupów. Najwięcej pomocy potrzebują przy załatwianiu spraw urzędowych i u lekarza. (O1)

Kompetencje oraz poziom funkcjonowania mieszkańców decyduje o zakresie udzielanego wsparcia (Zasępa, 2017). Niektórzy mieszkańcy z powodu deficytów wymagają wsparcia przez świadczenie usług. Pomoc ta polega na wykonywaniu czynności dnia codziennego oraz czynności, które wymagają dużego nakładu pracy i wysiłku (Kawczyńska- Butrym, 1998). Protegowani, którzy wymagają wsparcia podczas wykonywania czynności pielęgnacyjnych: kąpiel, umycie zębów lub czynności porządkowych jak wykonanie pranie, mogą zawsze liczyć na pomoc ze strony opiekuna mieszkania.

4 „J”, „D”, „G” oznacza inicjał imienia autora słów, oznaczenie „1.23”, „1.53”,lub „1.36” wskazuje na wiek respondenta. 
Mieszkańców wspierają opiekunowie. Osoby, które z nimi przebywają. To oni są wzorem w postępowaniu. To opiekunowie wyznaczają kierunek działań. (O2)

(...) U osób, które nie posiadają prawnego opiekuna sprawy przejmuje opiekun mieszkania. Pomoc polega na nieustannym nadzorowaniu tego co robią w domu i poza nim. Nie chodzi o wyręczanie, a raczej o pokazanie jak zrobić coś poprawnie. Czasami nauczanie prowizorycznie prostej czynności jaką może być zrobienie prania trwać może miesiącami. (O1)

Tak więc, mieszkańcy doświadczają wsparcia społecznego rozumianego jako pomoc świadczona m.in. przez osoby, z którymi pozostaje się w kontaktach więzi oraz w środowisku, w którym przebywają (Maciarz, 1992). Tymi źródłami wsparcia są inni mieszkańcy oraz opiekunowie.

\section{Dyskusja wyników badań}

Badania i rozważania podjęte w pracy nie wyczerpują problematyki związanej z ideą mieszkalnictwa wspomaganego w sferze wsparcia osób z niepełnosprawnością intelektualną. Odpowiadając na postawione pytanie badawcze: jakie jest wsparcie osób z niepełnosprawnością intelektualną na przykładzie mieszkalnictwa wspomaganego, można rzec, że jest to odpowiedni rodzaj wsparcia dla osób niepełnosprawnych. To miejsce, gdzie udzielana jest pomoc w obszarze codziennego życia i funkcjonowania. Kluczową rolę w mieszkaniu spełniają opiekunowie mieszkania. Ustalona przez nich struktura dnia oraz kierunek działań pozwalają na budowanie zaradności w zakresie samodzielności i samoobsługi przez protegowanych mieszkania. Opiekunowie prezentują mieszkańcom zróżnicowane formy spędzania wolnego czasu. Pobyt w mieszkaniu pozwala również rozwijać kompetencje społeczne. Nauka rozwiązywania wszelkich konfliktów w relacjach pomiędzy mieszkańcami opiera się na wskazywaniu prawidłowych wzorców postępowania, jaką jest spokojna rozmowa.

Badane mieszkanie działa zgodnie z założeniami tej usługi. W Polsce mieszkalnictwo wspomagane jest jedną z głównych usług, świadczącą wsparcie wobec osób dorosłych z niepełnosprawnością intelektualną w zakresie nauki prowadzenia jak najbardziej „normalnego” życia. Mieszkalnictwo wspomagane umożliwia rozwój w różnych obszarach funkcjonowania, co daje tym osobom szansę na w miarę niezależną przyszłość.

\section{Podsumowanie}

Pobyt w mieszkaniu wspomaganym jest bardzo cennym wsparciem dla osób z niepełnosprawnością intelektualną. Mieszkanie pozwala na usamodzielnienie oraz ćwiczenie zaradności życiowej tych osób oraz zapobiega umiesz- 
czeniu ich w placówkach opieki całodobowej(www.rpo.malopolska.pl/download/Model_mieszka_wspomaganych_dla_niepenosprawnych_intelektualnie_31_08_2015.pdf, dostęp: 15.01.2020). Przeprowadzone badania powinny przyczynić się do dalszych rozważań w tym kontekście badawczym. Pomimo udzielanego wsparcia, osoby z niepełnosprawnością intelektualną w stopniu umiarkowanym i znacznym ze względu na swój ograniczony rozwój intelektualny i deficyty rozwojowe, nie są w stanie prowadzić w pełni samodzielnego życia. Osoby te wymagają pomocy ze strony osoby pełnosprawnej w codziennych sprawach. Zakres ten obejmuje: zarządzanie pieniędzmi, przygotowywanie posiłków czy załatwianie spraw w miejscach użyteczności publicznej. Warto zastanowić się nad poszerzeniem, zgłębieniem zakresu udzielanego wsparcia osobom z niepełnosprawnością intelektualną, by móc zmienić obecnie panującą rzeczywistość. Proces rehabilitacji osób z niepełnosprawnością intelektualną skoncentrowany na zdobywaniu samodzielności, nabywaniu kompetencji społecznych i niezależności życiowej jest długotrwały, dlatego też powinien on być już rozpoczęty od najmłodszych lat życia. Biorąc pod uwagę zakres wsparcia udzielanego przez mieszkalnictwo wspomagane, warte zbadania są zmieniające się relacje pomiędzy mieszkańcami na przestrzeni lat, co pozwoliłoby na uzyskanie informacji dotyczących rozwoju ich kompetencji społecznych. Ponadto, warto sprawdzić, czy zakres wsparcia udzielany przez mieszkalnictwo wspomagane pozwolił na osiągnięcie przez podopiecznych, takiego stopnia samodzielności, który pozwoliłby na opuszczenie mieszkania i prowadzenie samodzielnej egzystencji, przy niewielkim wsparciu osoby pełnosprawnej. Kolejny aspekt, który jest godny zbadania, to zdobyta samodzielność przez mieszkańców w opinii ich oraz opiekunów mieszkania. Ostatnia kwestia, która się nasuwa to: wpływ wsparcia udzielanego przez mieszkalnictwo wspomagane na funkcjonowanie mieszkańców w społeczności lokalnej lub pracy zawodowej.

\section{BIBLIOGRAFIA}

Bakiera, L. i Stelter, Ż. (2010). Wspomaganie rozwoju osób niepełnosprawnych intelektualnie, W: A.I. Brzezińska, R. Kaczan i K. Smoczyńska (red.), Diagnoza potrzeb i modele pomocy dla osób z ograniczeniami sprawności (s. 143-162). Warszawa: Wydawnictwo Naukowe Scholar.

Bendkowski, J. (2016). Badania jakościowe - wybrane problemy, odniesienia do logistyki stosowanej. Zeszyty Naukowe Politechniki Śląskiej, nr 89, 25-38.

Chrzanowska I. (2019). Pedagogika specjalna. Od tradycji do współczesności. Kraków: Oficyna Wydawnicza Impuls.

Jemielniak D. (2012). Badania jakościowe. Metody i narzędzia. Warszawa: Wydawnictwo Naukowe PWN.

Kacperczyk, A. (2006). Wsparcie społeczne winstytucjach opieki paliatywnej i hospicyjnej. Łódź: Wydawnictwo Uniwersytetu Łódzkiego. 
Kawczyńska-Butrym, Z. (1998). Niepetnosprawność - specyfika pomocy społecznej. Katowice: Wydawnictwo Śląsk.

Kodeks etyki socjologa (2012). Uchwalony przez Walne Zgromadzenie Delegatów Polskiego Towarzystwa Socjologicznego 25 marca 2012. Warszawa.

Kutek-Sładek, K. (2015). System wsparcia osób z niepełnosprawnościami i ich rodzin w Polsce. W: G. Godawa (red.), Pedagogiczne konteksty społecznego wsparcia rodziny (s. 179-205). Kraków: Uniwersytet Papieski Jana Pawła II, Wydawnictwo Naukowe.

Łobocki, M., (2003). Metody i techniki badań pedagogicznych. Warszawa: Oficyna Wydawnicza Impuls.

Maciarz A. (1992). Wspomaganie rodziny w wychowaniu i rehabilitacji dzieci. Problemy Opiekuńczo-Wychowawcze, $\mathrm{nr}$ 5/6, 254-257.

Marciniak-Madejska, N. (2013). Życie dorosłych osób z niepełnosprawnością intelektualną - problematyczność realizacji potrzeby seksualności i niezależności w perspektywie rozwoju tożsamośći. Interdyscyplinarne Konteksty Pedagogiki Specjalnej, nr 2, 115-131.

Marciniak-Madejska, N. (2014). Mieszkalnictwo wspomagane dla osób z niepełnosprawnością intelektualną. Niepetnosprawność i Rehabilitacja, nr 1, 94-116.

Nieporowski, P. (2015). Etyka niejawnej obserwacji uczestniczącej jako metody badawczej stosowanej w naukach społecznych, W: M. Szumigraja, E. Trębińska-Szumigraj i D. Zielińska-Pękał (red.), Rocznik Lubuski. Badania jakościowe w poszukiwaniu dróg i inspiracji (s. 67-76), Zielona Góra: Oficyna Wydawnicza Uniwersytetu Zielonogórskiego.

Pilch, T. (1998). Zasady badań pedagogicznych. Warszawa: Wydawnictwo Akademickie Żak.

Przybyłowska, I. (1978). Wywiad swobodny ze standaryzowaną listą poszukiwanych informacji i możliwości jego zastosowania w badaniach socjologicznych. Przegląd Socjologiczny, nr 30, 53-68.

Sztompka, P. i Bogunia-Borowska, M. (2008). Socjologia codzienności. Kraków: Wydawnictwo Znak.

Zasępa, E. (2017). Osoba z niepetnosprawnościq intelektualną. Procesy poznawcze. Kraków: Oficyna Wydawnicza Impuls.

\section{NETOGRAFIA}

www.rpo.malopolska.pl/download/Model_mieszka_wspomaganych_dla_niepenosprawnych_intelektualnie_31_08_2015.pdf (dostęp: 15.01.2020).

(https://sjp.pwn.pl/slowniki/protegowany.html, dostęp:15.01.2020).

\section{SUMMARY}

\section{Support of People with Intellectual Disability on the Example of Assisted Housing}

The concept of supported housing has been described many times, but despite this, there is little research on the extent of support provided by supported housing for people with intellectual disabilities. Therefore, in conducting this research, I sought to answer the question: what is the support provided by assisted housing for people with intellectual disabilities? The research was conducted in one of the Supported Apartments for people with intellectual disabilities in Sosnowiec, Poland. I collected the necessary materials by using the method of direct participant observation and semi-structured direct interview. The research presented here shows the range of support provided by supported housing. Organizing the day, preparing meals, and resolving conflicts are essential skills that should be developed from an early age.

KEYWORDs: people with intellectual disability, support, assisted housing 